\title{
Foreningskrise i mellemkrigstiden - om ungdom og idræt på landet
}

\author{
Af Niels Kayser Nielsen
}

Det er blevet en hævdvunden tanke i dansk idræt, at der skulle eksistere et modsætningsforhold mellem på den ene side gymnastikken og på den anden side sporten. Denne tanke blev for alvor slåt fast med Ove Korsgaards værk Kampen om kroppen fra 1982. Her bruges bl.a. historien om K.A. Knudsens rejse til England i 1894, hvor han oplevede to vidt forskellige måder at springe højdespring på: en gymnastisk-harmonisk og en sportiv udførelse, som udgangspunkt for opstilling af modsætning mellem gymnastik og sport. ${ }^{1}$ Denne modsætning, der er bogens bærende idé, hævdes at omfatte ikke blot idræt, men også politisk-kulturelle dispositioner og livssyn, således at der skulle være tale om to vidt forskellige kulturer. Disse to kulturer, mener Korsgaard, repræsenterer henholdsvis landet og hovedstaden, således at provinsen især var gymnastikpræget, medens hovedstadens bykultur var sportiv. $^{2}$ Modsætningen siges også at vedrøre sammenhold overfor fri konkurrence, enkeltmandspræstationer og borgerlig individualisme. $^{3}$

Villet eller ikke-villet er Korsgaards synspunkter blevet brugt som led i cementeringen af det politisk-organisatoriske modsætningsforhold mellem på den ene side DDGU (DGI) og på den anden side DIF. Uheldigvis er Kampen om kroppen - dens mange fortræffeligheder i $\varnothing$ vrigt ufortalte kommet til at sætte en bestemt, kodificeret dagsorden for opfattelsen af relationen mellem de to store idrætsorganisationer og for opfattelsen af dansk idrætshistorie

Eller sagt på den anden måde: bogens virkningshistorie har ikke mindst gjort sig gældende politisk, hvor man mere har haft behov for at legitimere sig organisatorisk end for at søge nye erkendelser. Ikke mindst fra gymnastikside har man siden 1982 trukket på den påståede modsætning. Ved passende lejligheder hives den gamle traver af stald, og i højstemte, retoriske vendinger trækker man da linjerne op og gør rede for dette modsætningsforholds rødder. Idrætshistorien bruges som belæg for den bevarelse af to store idrætsorganisationer, som er blevet en kongstanke for DGI, medens DIF i højere grad går ind for en énhedsmodel.

Spørgsmålet er imidlertid, om dette modsætningsforhold har historisk gyldighed. Måske er modsætningsforholdet op igennem det 20. århundrede mere af organisatorisk end af egentlig idrætslig art. Måske er Korsgaard for unuanceret $\mathrm{i}$ sin opstilling af en polaritet mellem gymnastik på landet og sport i byerne. Man kunne i den forbindelse, forsigtigt, stille spørgsmålet, om det ikke snarere er kampen for to forskellige organisationer, der er det centrale, end kampen for to forskellige slags idrætter. Det er tesen i denne artikel, at der på landet - hvor modsætningsforholdet mellem gymnastik og sport hævdes at være og have været størst - allerede i mellemkrigstiden var tale om et suppleringsfor- 
hold mellem de to idrætstyper og ikke et modsætningsforhold. Hvis dette er tilfældet, er det således tvivlsomt, om der fortsat --i det mindste hvis vi ser på den folkelige idræt på landet - kan argumenteres idrætshistorisk for opretholdelsen af de to store hovedorganisationer - hvilket selvsagt ikke forhindrer muligheden for andre typer af argumentation og andre legitimeringer af bevarelsen af den særegne danske organisatoriske dualisme.

\section{Sport $i$ Vejen}

At gymnastik, højskole og sport aldrig har haft det anstrengte forhold til hinanden, som man ellers antager, får man et indtryk af, hvis man kaster et blik på et af højskolebevægelsens arnesteder, nemlig Askov. Netop her kunne man forvente, at gymnastikken, som skulle være højskolebevægelsens kropskultur par excellence, ville være enerådende. Det har dog aldrig været tilfældet. I Askov og den nærliggende stationsby Vejen var der fra århundredskiftet tale om en tæt forbindelse mellem højskolen og den unge sportsbevægelse, hvor højskolemiljøet et par kilometer uden for Vejen bakkede op om sporten.

Beliggende på banelinjen mellem Kolding og Esbjerg udviklede der sig i Vejen tidligt en omfattende industri med en tilhørende befolkningsvækst, fra 657 i 1890 til 2829 i $1921,{ }^{4}$ ligesom den grundtvigianske højskolebevægelse her var i kraftig vækst. Mellem disse to miljøer herskede der ikke et modsætningsforhold, men tværtimod en ganske tæt og intim relation, baseret på gensidig sympati. Begge miljøer blev ledet af hver sin stærke og magtfulde »konge«. På Askov herskede forstander Ludvig Schrøder, i Vejens industrimiljø sad fabrikant Johannes Lauridsen på tronen. Begge disse mænd var driftige og energi- ske ledere med udsyn og visioner, og begge var de interesserede $\mathrm{i}$ såvel den åndelige som den timelige verden.

Forstander Schrøder er undertiden blevet fremstillet som en lidt distræt og verdensfjern højskolemand med hang til vidtløftigheder. Imidlertid var han også en uhyre praktisk tænkende mand, der fuldt ud forstod sig på materielle forhold og bondepraktik. Da Schrøder og hans hustru i 1887 kunne fejre sølvbryllup, betænkte deres venner ægteparret med en større pengegave. Den ville Schrøder, til stor forargelse for børnene, have brugt til en ajletønde på sin gård; dog sørgede den magtfulde fru Schrøder for, at der også kunne blive råd til et skab til familiens sølvt $\varnothing j^{5}$ ) I det hele taget gik Schrøder med liv og sjæl op i sit landbrug på Damgaarden, ikke mindst kvægbruget. Han havde en række meget fine køer i sin stald. Den fineste, der blev stammoder til en hel familie, hed »Gl. Gram«. Skelettet af den blev senere opstillet på Ladelund Landbrugsskole til gavn for anatomiundervisningen dér, og det fortælles, at på Konrad Jørgensens trykkeri i Kolding, hvor bl.a. Højskolebladet blev trykt, var de to mest brugte klicheer billederne af Grundtvig og Gl. Gram. Ligeledes kom Schrøder i nært forhold til C. F. Tietgen og benyttede ofte lejligheden til at berømme ham over for eleverne på Askov. ${ }^{6}$ Højskolemanden Schrøder var ikke blind for borgerlig individualisme og enkeltmandspræstationer. Og man kan i det hele taget ikke se bort fra det paradoksale forhold mellem betoningen af både kooperation og heltedyrkelsen af store mænd, såsomGrundtvig og Kold, inden for højskolebevægelsen.

Tilsvarende var Johannes Lauridsen på gården Grønvang ikke kun en åndløs kapitalist. Han deltog aktivt i Vejens sociale og kulturelle liv. Og den opvakte og vidt for- 
grenede Lauridsen-familie var blandt medstifterne af Dansk Højskoleforening i 1878, ligesom familien tilhørte kredsen af Askov Højskoles nærmeste venner. Således var det Poul la Cour på Askov - et af medlemmerne af den berømte »Norrlander-tylvt «, der var med til at introducere den svenske gymnastik i Danmark - som navngav Johs. Lauridsens margarinefabrik Alfa. ${ }^{7}$ I bestyrelsen herfor sad udover J. Lauridsen selv bl.a. også hans broder, købmand Peter Lauridsen og Poul la Cour. Udover margarinefabrikken »sad « Lauridsen på tagpapfabrikken Phønix, hvis første direktør i 1909 blev sønnen Olav Vang Lauridsen, ligesom han allerede i 1878 havde startet Cikorietørreriet, som ved siden af teglværkerne var Vejens ældste industrivirksomhed. Han var formand for bestyrelsen i både mejeriet og svineslagteriet. Ligeledes havde han startet en såkaldt »engforening «, der satsede på dambrug. Johannes Lauridsen var desuden

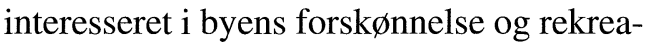
tive forbedring og var således formand for det konsortium, der havde opk $\varnothing b t$ en landejendom med henblik på at skabe et anlæg. Endelig var han også interesseret i idrætssagen. Han havde været blandt lederne i skytte- og gymnastikforeningen i Vejen, ${ }^{8}$ og der er al mulig grund til at tro, at han har støttet, at man fra Vejen i 1885 lod snedkersvend Laurids Vig sende til Lund for at deltage i det ovennævnte kursus, som kaptajn Norrlander dér lod holde for 12 danske deltagere. Udover Laurids Vig indgik heri altså også Poul la Cour fra Askov, der blev »Norrlander-tylvtens « åndelige leder.

Allerede april 1899 forhandlede sportsforeningen med fabrikant Johs. Lauridsen om en spilleplads ved fabriksanlægget, som blev bevilget mod en lejepris på $30 \mathrm{kr}$. for sommeren 1899. ${ }^{9}$ Det skete året efter, at han bekostede omdannelsen af det gamle biblioteksrum på Askov Højskole til et styrtebadsrum. I 1902 køber Sportsforeningen egen bane ved Nørregade. Man betaler $1362 \mathrm{kr}$. for 2 tønde land jord plus $250 \mathrm{kr}$. for en adgangsvej gennem landpost Petersens have. Til gengæld tilbyder sognerådet at overtage arealet og garantere eller udbetale resten af købesummen, dog ikke over $1000 \mathrm{kr}$., mod at idrætsforeningen som modydelse for brugsretten afdrager og forrenter disse penge, og mod at kommunens skolesøgende børn har adgang til baneanlægget. Formanden for sognerådet var Johs. Lauridsen.

Men også på den aktive front tager familien Lauridsen del i idrætslivet i Vejen. År 1900, da Vejen på Alfa-anlægget for første gang spiller mod et københavnerhold, B93, er Johs. Lauridsens søn Olav Vang Lauridsen målmand på holdet, ligesom en anden søn spiller back på fodboldholdet i 1907. En modsætning mellem højskoleverdenen og sportsverdenen kan man vanskeligt få øje på: året efter at Olav Vang Lauridsen står på mål for fodboldholdet, tager han om vinteren på Testrup Højskole, hvor den kendte skyttesags- og gymnastikmand Jens Nørregaard var forstander. ${ }^{10}$

Hvorfra Johs Lauridsen har hentet sin idrætsinteresse, ved vi ikke med sikkerhed. Måske fra sin broder Jeppe Lauridsen, der var en ivrig bryder, og som en gang i sin ungdom i Vejen havde besejret en tysk bryder og cirkusdirektør, og som senere ved den store gymnastikfest for hele landet $\mathrm{i}$ Nyborg i 1880 havde kastet en stor og stærk skorstensfejer fra Odense. ${ }^{11}$ Da Vejen Sportsforening i 1890 indleder sine aktiviteter, er hovedmændene bag initiativet henholdsvis privatlærer Hans Birkelund, som underviste på gården Grønvang, dvs. hos Johannes Lauridsen, og Olivarius Jürgensen, ${ }^{12}$ som var kommis hos købmand Peter Lauridsen, Johs. Lauridsens broder, der ligeledes havde forbindelse til højsko- 
len. Askov Højskole var på daværende tidspunkt inde $\mathrm{i}$ en idrætslig frugtbar gæringsperiode, hvor den dynamiske Inge-borg Schrøder, uden korset og i fri reformgymnastikdragt, fra sommeren 1889 havde overtaget undervisningen i kvindelig gymnastik og sundhedslære, og hvor hendes tilkommende Jacob Appel, den senere undervisningsminister, i 1890 blev tilbudt en lærerstilling - omend han var meget lidt glad for at se sin Ingeborg i reformdragt. ${ }^{13}$

I en dagbog fra 1890 og frem kan man se, at der fra starten var tætte forbindelser fra idrætten i Vejen til familien Lauridsen, som altid havde været delagtig i højskolebevægelsen. Vejen Sportsforening havde på dette tidspunkt, i december 1890, udelukkende fodbold på programmet. Fem år senere kan man af referatet fra en ekstraordinær generalforsamling se, at lærer Birkelunds afløser som huslærer på Grønvang indvælges $\mathrm{i}$ bestyrelsen for Sportsforeningen, hvilket atter bekræfter forbindelsen mellem højskolemiljøet, Lauridsens og sportsforeningen. ${ }^{14}$ Familien Lauridsen skulle igen og igen vise sig at være til uvurderlig hjælp for sporten i Vejen. - Det gjaldt også i mellemkrigstiden.

Sport i Vejen var i mellemkrigstiden så godt som udelukkende ensbetydende med fodbold. Det er i denne periode, især i 1930 'erne, at stationsbyholdet gør sig gældende blandt landets førende hold. Og det er i denne periode, at udtrykket de $\gg$ jyske skotter « vinder udbredelse, idet det hed sig, at Vejen spillede lige så godt som de dengang så berømte skotske fodboldspillere. Klubben spillede igennem det meste af tiden den jyske mesterrække. Den vandt man ved et par lejligheder, fx i sæsonen 193637, og blev jysk mester foran så stærke klubber som AGF, Esbjerg fB og Vejle. Det betød, at man efter sæsonen 1936-37 rykkede op i 1. division, der nu var landsdæk- kende, da DBU havde lavet en ny turneringsordning i 1936. Vejens oprykning kom således på et belejligt tidspunkt og vakte stor interesse, ikke mindst i København, hvor mange tilskuere ville i Idrætsparken for at se det jyske »bondehold «.

Der var tale om en yderst bemærkelsesværdig præstation. Grundene hertil er givetvis mange, men blandt de væsentligste må man pege på dels en utrolig lokal opbakning bag klubben, dels at klubben tidligt skaffede sig professionelle trænere, såsom Sophus »Krølben«, der arbejdede systematisk med seniorafdelingen og her prægede en teknisk spillestil, som smittede af på ungdomsafdelingen..$^{15}$

Endelig kan man ikke se bort fra Vejens erhvervslivs opbakning omkring klubben. Her var det i særdeleshed Olav Vang Lauridsen fra margarinefabrikken Alfa, som var klubben yderst venligt stemt. Således var det ham, der i 1931 gratis tildelte klübben 2,5 tønde land jord ved opførelsen af det nye stadion, som skulle afløse det gamle Nørregade-anlæg fra 1902, som faderen i sin egenskab af sognerådsformand havde skaffet idrætten på yderst favorable vilkår. ${ }^{16}$

I en tid med massearbejdsløshed som i trediverne var det også et aktiv for klubben, at man som arbejdsløs fodboldspiller kunne få arbejde på Alfa. Det er forkert at tale om professionelle tilstande i Vejen, og klubben var ikke et rent firmahold, men fremgangsmåden, at Vang Lauridsen skaffede arbejde på sin fabrik, blev benyttet i adskillige tilfælde. ${ }^{17}$ Flere af klubbens kendteste spillere i 1930'erne kom således udefra. Et sådant system var ganske udbredt i mellemkrigstiden, blot var det ekstraordinært tydeligt i Vejen. Det var ulempen ved at være en lille klub med stor succes, men det var på den anden side også en forlængelse af den tradition, som Johs. Lauridsen med 
udgangspunkt i højskoleidrætten havde etableret omkring århundredskiftet 1900.

Historien om idrætten i Vejen fortæller, at den traditionelle modstilling mellem gymnastik, højskole og præstationsundsigelse på den ene side og sport, idrætsforening og præstation på den anden side er alt for firkantet. Højskolerne og deres idræt var i høj grad en del af den samlede moderniseringen af bonde-Danmark og var i tilsvarende høj grad interesserede i vækst, produktivitet, konkurrence, præstation og dermed sport. Når man ser på idrættens historie på lokalt plan, udviskes den firkantetideologiske skelnen mellem højskoleidræt og sport yderligere. Det viser bl. a. historien om idrætten i Vejen, som via familien Lauridsen fra sin start er intimt forbundet med højskolernes højborg i Askov. Fællesnævneren var modernisering og folkeoplysning.

\section{DIF og Niels Bukh i tyverne}

Et andet udslag af denne modernisering kommer til udtryk i det samarbejde mellem Dansk Idræts Forbund (DIF) og Niels Bukh, som gjorde sig gældende omkr. 1920. Den sportive del af Danmark i regi af Dansk Idræts Forbund tog fra starten af Niels Bukhs højskole-gymnastik til sit hjerte. I DIF's årsberetning for året 1919 hedder det således, at

den Interesse, man oftere indenfor Dansk Idræts-Forbund havde udtalt overfor Niels Bukhs Arbejde, havde foranlediget, at ledende Mænd indenfor Dansk Idræts-Forbund havde støttet Bukhs Slid for at rejse et Gymnastik- og Idrætsinstitut til Uddannelse af lærere i Ollerup..$^{18}$

Således er DIF fra starten interesseret i hans arbejde, ligesom det er tydeligt, at DIF med det samme har øjnene åbne for de kolossale muligheder for at få ungdommen i idrætstale, der er knyttet til Niels Bukhgymnastikken. Vi kan se det allerede i 1917, hvor DIF foranlediger, at han i Odd Fellow Palæet for fulde huse kan vise den nye gymnastik, som han underviser delingsførerne i Skyttebevægelsen i. ${ }^{19} \mathrm{Her}$ er der intet modsætningsforhold hverken til Skyttbevægelsen eller til Niels Bukh. Det er der heller ikke i 1921, da man fra 26.9.22.10. i samarbejde med DDSG arrangerer et kursus for ledere og idrætsmænd $\mathrm{i}$ Idrætshuset, hvor der er lejlighed til at stifte bekendtskab med Niels Bukhs »primitive« Øvelser, som »for Tiden spiller en saa stor Rolle inden for Gymnastikuddannelsen i Skytteforeningerne«, som det hedder i DIF's årsberetning fra dette år. ${ }^{20}$ Kurset var gratis for instruktører og medlemmer af DIF. Man mente, at denne gymnastikform kunne få betydning som konditionstræning for alle idrætsmænd.

Der er ingen tvivl om, at man i DIF har fulgt Niels Bukhs arbejde nøje og med stor interesse. De mange invitationer til ham og opbakningen bag hans virke kan ikke opfattes på anden måde end, at DIF i disse år har været interesseret $i$ at knytte ham nærmere til sig, samtidig med at man på den anden side ikke ville ryge uklar med Skyttebevægelsen. På det store kursus på Garderhøjfortet i 1923 blev der således som den eneste type gymnastik undervist $i$ teori og praksis i den primitive gymnastik, ganske vist ikke af Niels Bukh selv, hvilket tydeligt nok viser, at DIF havde taget den til sig, men også at det var gymnastikken, mere end personen Niels Bukh, der var af interesse. ${ }^{21}$

Dette gensidighedsforhold på kursusplan mellem gymnastik og sport i begyndelsen af 1920'erne varede dog ikke ved. Én af årsagerne hertil var givetvis, at DIF entrerede med den svenske atletiktræner Carl Silfverstrand, som i disse år gjorde en stor indsats 
for at popularisere sporten i Danmark, og som efter sin ansættelse i Danmark ligeledes udrettede et stort arbejde i de finlandssvenske idrætsforeninger, bl.a. »Kiffen«, dvs. Kronohagens Idrottsförening i Helsingfors. ${ }^{22}$ Silfverstrand havde et interessant dobbeltforhold til gymnastikken. På den ene side roser han i 1922 Niels Bukh og hans system:

Det er virkelig Gymnastik, og i det Spor kommer Gymnastikken sikkert i Fremtiden til at slaa ind paa. Bukhs Gymnastik er en god Forskole for Idrætten med sine Smidigheds- og Muskeløvelser. ${ }^{23}$

På den anden side kristiserer han gymnastikken for, at gymnasten her står under en anden viljes indflydelse, nemlig delingsførerens, hvilket medfører, at gymnastens

Bevægelser ikke faar samme Frihed over sig (som idrætsmandens, NKN), de bliver mere tvungne, i Særdeleshed gælder dette under en Opvisning. ${ }^{24}$

Resultatet heraf er ifølge Silfverstrand tydeligt nok:

Den Gymnast der om Sommeren dyrker fri Idræt kan kun til en vis Grad frigøre sig fra denne »Stivhed $\ll .{ }^{25}$

For så vidt som Silfverstrands ord havde en betydelig vægt i instruktionsperspektiv i DIF i disse år, måtte sådanne udtalelser få en vis indflydelse.

Hvis vi til gengæld vender blikket bort fra den officielle kursusside i København og i stedet retter blikket mod idrætslivets hverdagsliv på landet, ser billedet noget anderledes ud. Så er det tydeligt, at afhængighedsforholdet mellem gymnastikken og sporten blev endnu mere markant længere op i mellemkrigstiden. B1. a. som følge af den foreningskrise, der slår igennem på landet omkr. 1930.

\section{Foreningskrisen i Danmark i mellemkrigstiden}

At foreningslivet i Danmark rammes af en generel krise i første halvdel af 1930'erne er efterhånden et velkendt fænomen. Det frivillige, ulønnede foreningsarbejde har det svært i disse år. Mange foreninger nedlægges eller ligger brak, enten på gr. af svigtende interesse i medlemsskaren, eller fordi det kniber at finde ledere og bestyrelsesmedlemmer. Som mulige årsager til krisen $\mathrm{i}$ foreningslivet på landet har man generelt peget på henholdsvis interne og externe faktorer, nemlig på den ene side landbrugets lavkonjunktur i disse år og på den anden side indflydelsen fra bykulturen, som synes at tiltrække større opmærksomhed blandt ungdommen på landet end den overleverede bondekulturs institutioner, der opfattes som værende præget af en inerti og traditionsælde, som ikke længere modsvarede forventningerne til samvær i foreningsregi. ${ }^{26}$ Således kan man næppe se bort fra, at mange unge, også på landet, i stigende grad simpelthen fandt gymnastikken for kedelig. Den var desuden henlagt til vinterhalvåret, så man savnede sommeraktiviteter, og den bar måske også i for høj grad præg af formanende foredragsholdere og stivnakkede delingsførere.

Generelt venter årsagerne til gymnastikforeningernes stagnation omkring 1930 imidlertid fortsat på at blive grundigt belyst. Meget tyder dog på, at deres nedgang for det første er led i en generel foreningskrise på dette tidspunkt, som ikke kun vedrører landbefolkningens gymnastikforeninger, men foreningslivet $\mathrm{i}$ det hele taget $\mathrm{i}$ Danmark.

Dette synes ikke at være et rent dansk fænomen. I Finland, hvor ungdomsforeningsbevægelsen på mange måder udgør den mest typiske nordiske pendant til den 
danske højskolebevægelse, kan man konstatere en lignende nedgang $-i$ det mindste i de svensksprogede dele af landet. Og på finsk hold kan man konstatere, at denne nedgang synes at hænge sammen med en stigende specialisering og uddifferentiering inden for ungdomsforeningerne: man nøjes ikke med én stor paraplyforening i kommunen, men etablerer flere foreninger på lokalplan, således at hver eneste lille landsby har sin forening, som hver især varetager sin snævre opgave: amatørteater, sang og musik, idrætsvirksomhed såsom ski og orientering etc. ${ }^{27}$

Noget lignende synes at gøre sig gældende herhjemme, sådan som man fx kan se det i Blåhøj i Midtjylland, hvor snart sagt hver eneste afkrog af sognet har sin egen lokale idrætsforening, som i regelen er i krise, og hvor der først sker en ændring i anden halvdel af 1930'erne, da idrætsforeningen i Blåhøj Stationsby med sporten som omdrejningspunkt opsamler de mange småforeninger og bringer dem ind under sig i en paraplyforening. ${ }^{28}$ Decentraliseringen havde, i det mindste i Blåhøj, sine grænser. Noget tilsvarende gælder i Ikast, hvor Ikast Forenede Sportsklubber blev stiftet i 1935 som en sammenslutning af tre mindre klubber, der fra ca. 1930 var i vanskeligheder: en boldklub som manglede en fodboldbane at spille på, en tennisklub hvis anlæg var beslaglagt til andre formål og en sportsskytteforening som slet ingen bane havde. ${ }^{29}$ I As mellem Horsens og Juelsminde var der indtil 1936 tre ungdomsorganisationer: gymnastikforeningen, ungdomsforeningen og boldklubben, som så finder ud af samle kræfterne med henblik på en centralisering af ungdomsarbejdet, hvorefter As Idrætsforening ser dagens lys i november $1936 .{ }^{30}$

Man kan for det andet pege på den generelle krise i begyndelsen af 1930'erne, som medførte et manglende overskud til at tage del i foreningslivet. Lidt mere konkret kan man i den forbindelse pege på den svigtende indtjening hos landbrugerne, som vanskeliggjorde et socialt og $\varnothing$ konomisk overskud til at lave foreningsarbejde for. Mange mente ikke at have råd til at betale kontingent, således at der blev færre medlemmer i foreningerne, hvilket i sin tur forskærtsede bestyrelsernes muligheder for at tilvejebringe en tiltrækkende virksomhed. Hertil kom vanskelighederne med at skabe den kontinuitet i bestyrelsesarbejdet, som alt andet lige må anses som væsentlig for et foreningsarbejde, der skal leve i et lokalområde. Her havde man det helt konkrete problem, som krisen også medførte for landbefolkningen, nemlig at karlene og pigerne som følge af lavkonjunkturen skiftede hyppigere plads. Det svækkede kontinuiteten $\mathrm{i}$ foreningsarbejdet, ikke mindst når man tager i betragtning, at mange af disse tjenestepiger og -karle ofte sad i bestyrelsen for idrætsforeningen. Når de så skiftede plads allerede efter et halvt år, enten for at hjælpe til derhjemme eller for at skaffe sig en bedre ansættelse andetsteds, eller for at tage ind til byen $\mathrm{i}$ håb om at finde lykken dér, måtte foreningerne igen ud for at lede efter bestyrelsesmedlemmer. ${ }^{31}$ Det kunne måske endda gå $\mathrm{i}$ forbindelse med pladsskifte til »majdag «, dvs. 1.5. hvor gymnastikken alligevel lå stille, men skiftede man plads til 1. november, hvor foreningslivet igen skulle til at blomstre op, så det værre ud; så var gymnastikken for alvor i fare.

Hvad angår bykulturens indflydelse i landområderne kan man for det første pege på den nye bilisme, som gjorde det muligt for landboungdommen at tage del i den nye fremvoksende bykultur. Ganske vist var privatbilismen kun forbeholdt de færreste, men et hastigt fremvoksende net af rutebiler gjorde det muligt at komme rundt til an- 
dre og mere tiltrækkende arrangementer end foredraget og gymnastikken i forsamlingshuset. Om sommeren kunne man leje en lastbil med bænke og stole på ladet og så tage af sted på udflugt. Det fysiske rum blev betragteligt udvidet i mellemkrigstiden og dermed erfaringsmængden. I den forbindelse skal man ved siden af rutebilerne heller ikke underkende motorcyklen for slet ikke at tale om cyklen, som også bidrog til udvidelse af det sociale rum. I mellemkrigstiden regnede man det ikke for et problem at cykle ind til den nærmeste købstad eller til større byer som Aarhus, Odense og København - om ikke andet så for at opleve noget nyt. Der var i disse år en brændende interesse for at se og høre nyt og for at tage del i de tekniske og kulturelle fremskridt, og meget af 1930'ernes friluftsliv havde cykelsadlen som bastion. Som påpeget af den svenske etnolog Jonas Frykman var 1930'erne også et tiår, hvor man, ikke mindst kropsligt og bevægelseskulturelt, trænede $i$ at godtage og anerkende nye og anderledes samfundsmæssige fænomener og tilstande..$^{32}$

Man kan dernæst pege på triviallitteraturen. Den var begyndt med den billige boulevardpresse allerede før århundredskiftet, men blev i 1930'erne fulgt op med ugeblade som Hjemmet og Billed Bladet og seriehefter om bl.a. Skipper Skrak samt billige knaldromaner. Denne type litteratur begyndte nu at trænge ind på den traditionelle læseforenings enemærker med dens bøger skrevet for landboere om landboere. Nu begyndte andre livserfaringer at blive tematiseret. Læsning i landsognene var ikke længere udelukkende ensbetydende med historier om forpinte hovbønder og heroiske andelsbønder og andre sådanne tematiseringer af gårdmandserfaringer. Repertoiret blev nu udvidet med bylivshistorier, som beskæftigede sig med nye konflikter.
I mellemkrigstiden vandt også filmen udbredelse landet over. Således lå halvdelen af de godt 350 biografer i landdistrikterne, i regelen placeret i stationsbyerne, og omkring 1940 var der så mange biografpladser, at ca. 100.000 danskere kunne se film på én gang. Filmhelte som Margerethe Viby, Ib Schønberg og Peter Malberg blev nu folkeje, ligesom lystspillenes og folkekomediernes filmmelodier blev landskendte.

Hertil kommer det nye »demokratiske « massemedie: radioen, der fik sit gennembrud i 1930'erne. Medens lytterantallet i begyndelsen af 1920'erne kun udgjorde et par tusinde, var man i 1940 oppe på næsten 1 million. Radioen med dens transmissioner af politiske diskussioner, koncerter, sportsbegivenheder og hørespil samt »neutrale« nyhedsudsendelser blev hermed landets måske mest samlende kulturfaktor. For landbokulturen betød dette, at det lokalt særegne i nogen grad tabte i værdi til fordel for det fælles og almene. Hvor forsamlingshuskulturen tidligere havde været fællesnævneren for store dele af befolkningen, fik man nu i form af de nye massemedier med radioen i spidsen - yderligere en fælles reference i form af massekulturen.

På den baggrund blev det svært at fastholde en homogen landbokultur. På grund af de mange nye fristelser fra byerne og stationsbyerne, med biografer og VU-baller på kroen eller i Håndværkerforeningens lokaler i købstaden, var den lokalt baserede landbokultur med forsamlingshuset som ramme for et gårdmandsdomineret sogneliv i færd med at tabe i værdi. Ganske vist rejste det nye ofte modstand. Således kan det nævnes, at det vakte voldsom furore $\mathrm{i}$ missionske kredse i Aulum, da dyrlægen sammesteds i 1936 slog til lyd for oprettelsen af et moderne friluftsbad, så at befolkningen ikke længere skulle bade $\mathrm{i}$ åer og 
mergelgrave. ${ }^{33}$ Og ganske vist var der i mellemkrigstiden også tale en vis indflydelse fra landbokulturen på bykulturen, ikke mindst i form af en dyrkelse af det »sunde« og »friske« liv på landet, men overordnet var tendensen tydelig nok:

Landbokulturens særlige kropskulturelleaspekt, centreret omkring gymnastikken og folkedansen, synes i mellemkrigstiden at have haft svært ved at overleve i sin traditionelle udformning. I protokollen fra Gårslev Idrætsforening mellem Fredericia og Vejle kan man i 1948 læse følgende klare tegn på udhuling af bondekulturen:

Der blev bestemt at vi skulde have Folkedanseafslutning. Tirsdag d. 16. 3. Saa skal vi først danse Gammeldavs og saa Kaffe med Revy til medbragt Brød, derefter Swing og Jass og saa hjem i Kassen.. ${ }^{34}$

Ganske vist stammer dette citat fra fyrrerne, men tendensen var klar allerede i trediverne, og situationen i Gårslev sammenfatter blot den udvikling, der længe havde været i gang. Tilsammen vanskeliggjorde disse samfundsmæssige forandringer opretholdelsen af den traditionelle, særegne landbo-kropskultur med gymnastikken om vinteren i forsamlingshuset som fælles holdepunkt. Spørgsmålet er imidlertid, i hvor høj grad der nogensinde har været tale om en sådan særegenhed. Hvis man, som gængs er, udgår fra en tæt forbindelse mellem gymnastikken og højskolerne, må det i den forbindelse være et memento, at $\mathrm{h} \varnothing \mathrm{j}$ skolerne (jvf. ovenfor om Askov/Vejen) ikke har været så fremmede overfor konkurrencesporten som tidligere antaget, og som vi skal se nedenfor, blev $\mathrm{fx}$ håndboldspillet mange steder på landet introduceret af delingsførere, som havde været på højskole, typisk på Ollerup.

\section{Sportens gennembrud $i$ Gudbjerg, Østermarie og Trelde}

På baggrund af den foreningskrise, hvis mulige årsager der nu er peget på, må det næste forehavende være at undersøge, hvordan det kunne gå til, at idrætsforeningerne på landet så alligevel overlevede, og endda var inde i en kraftig vækst fra midten af 1930'erne - en vækst som blev yderligere styrket under 2. verdenskrig. Til det formål kan man - i stedet for kun at holde sig til det organisatoriske plan - med fordel dykke ned i idrætslivets hverdagsliv, sådan som det udfoldede sig lokalt. Den lokalhistoriske dimension kaster ofte nyt lys over de generelle betragtninger vedrørende situationen på landsplan.

Lad os i den forbindelse gå til et af højskolebevægelsens kerneområder, nemlig Sydfyn, nærmere bestemt landsbyen Gudbjerg. Her fandtes der i 1920 'erne i god overensstemmelse med egnens generelle praksis en Skytte- og Gymnastikforening med aktiviteter, der var præget af nærheden til Ollerup Gymnastikhøjskole, og et lederpar, Jørgen Buhrkal og frue, som skønt uden delingsføreruddannelse var stærkt Niels Bukh-påvirkede. Da de flytter fra sognet i 1929, er der imidlertid ikke kraft og vilje til at videreføre arbejdet, og foreningen ligger stille i ca tre år, hvor både gymnastikken og skydningen synes at gå en langsom død i møde og først kommer på fode igen i 1932 og $1933 .{ }^{35}$ Vinteren $1933-$ 34 overtager gårdejer Jakob Dyhr, lige hjemvendt fra Ollerup, karlegymnastikken. Han bliver med en tydelig påvirkning fra Kristian Krogshede den ny inspirator og får for alvor gang i idrætslivet i Gudbjerg. $\mathrm{Og}$ hvordan kunne det så gå til?

Rent bortset fra dimensionen charisma, der i følge Max Weber er én af historiens 
store drivkrafter, og som Jakob Dyhr vistnok har haft masser af, kan man ikke se bort fra, at ændringerne i idrætsaktiviteter-ne i Gudbjerg har spillet en væsentlig rolle. Sammen med broderen Rasmus sætter Jakob Dyhr ikke kun skub i gymnastikken. Han indfører også atletik, ligesom han introducerer syvmands-håndbold, hvor Gudbjerg hurtigt bliver ét af Sydfyns bedste hold. At håndbolden virkelig blev en succes, kan man se af den omstændighed, at 4. herrehold i 1942 bliver hovedkredsvinder og dernæst vinder amtsmesterskabet for 4 . hold. Der har været mange håndboldspillere i Gudbjerg i disse år. I 1945 vinder 3. herrehold hovedkredsen, medens 4 . holdet gentager succes'en i 1947 og atter vinder amtsmesterskabet. En passant kan det nævnes, at Gudbjerg Idrætsforening i dag indgår i den store håndboldklub GOG.

Krigsårene blev i Gudbjerg som så mange andre steder i landet en opgangsperiode for idrætten. Og idrætsrepertoiret var nu blevet væsentligt udvidet. Ikke kun gymnastik, skydning og håndbold, men også badminton - i en selvstændig badmintonklub - stod på programmet i disse år med stor tilslutning. I 1941 havde forsamlingshusbestyrelsen ellers afslået badmintonspillernes anmodning om at låne forsamlingshuset tre aftener om ugen. Man kunne heller ikke akceptere, at disse spillere ville »tegne kryds- og tværsopgaver på gulvet med maling «. ${ }^{36}$ I 1944 var situationen imidlertid anderledes. Badmintonspillet, der i løbet af 1930'erne havde oplevet en kolossal succes ikke kun i byerne, men også på landet, ${ }^{37}$ blev nu også akcepteret i Gudbjerg. Badmintonklubben arrangerede udflugt til Svendborg, hvor man spillede kampe på tennishallens fem baner og derefter fortsatte til Thurø Kro, hvor der var selskabeligt samvær. Også skytte-, gymnastik- og idrætsforeningen arrangerede udflugter.
Idrætslivet var i disse år langt mere socialt aktivt end dengang, hvor man kun havde gymnastik som aktivitet. Udflugterne og festerne spillede her en ikke uvæsentlig rolle.

Til trods for at Gudbjerg er beliggende midt $\mathrm{i}$ det traditionelt set »vakte « sydfynske område og på trods af forbindelser til højskoleverdenen, forhindrede dette - ligesom i Vejen - ikke, at den sportslige side af idrætten blev højt prioriteret siden introduktionen af sport i 1930'erne, samtidig med at »gamle« idrætter som skydning og gymnastik blev ført videre og endda fra 1935 blev suppleret med folkedans. Og så er det måske endda forkert at sige $»$ på trods af «, hvad angår forbindelsen til højskoleverdenen. Måske skulle man snarere sige »på grund af «: Det var jo netop på Ollerup, at Jakob Dyhr havde stiftet bekendtskab med håndbold og atletik. I den forbindelse kan man heller ikke se bort fra, at den Niels Bukh-påvirkede Jørgen Buhrkal allerede sidst i 1920 'erne lagde vægt på fart og flugt over gymnastikøvelsernes afvikling. ${ }^{38}$ Jorden var således gødet for introduktionen af den mere dynamiske sport.

I Østermarie på Bornholm ligger idrætslivet i dvale i begyndelsen af 1930'erne, sådan som tilfældet i øvrigt var på Bornholm, ikke mindst i årene 1930-32. ${ }^{39}$ Skytte- og gymnastikforeningen er kommet ud i uvejr. Angiveligt som et resultat af den pacifistiske agitation, der kendetegnede 1920 'erne, som stillede skyttesagen i et dårligt lys, og som også i Østermarie betød skærmydsler mellem skytter og gymnaster. ${ }^{40}$ Men heller ikke gymnastikken har succes. Derfor beslutter man i 1935 på en ekstraordinær generalforsamling at dele foreningens regnskab - der beløber sig til et underskud på $564 \mathrm{kr}$. samt sparekasselån på $350 \mathrm{kr}$. og en gældspost til en privatperson på 114 kr. - op i to adskilte afdelinger. Gym- 
nastikfolkene kører nu selvstændigt videre med fornyede kræfter. Man stabler en gymnastikopvisning på benene og udnævner et:æresmedlem! Altsammen i traditionel stil. Men som noget nyt starter man i 1936 også andespil med efterfølgende bal på Hotel Østermarie. I 1939 tales der på generalforsamlingen om mulighederne for at spille badminton, ligesom man til gymnastikopvisningen dette år vælger at invitere Østermarie Idrætsforening. ${ }^{41}$ Denne var blevet stiftet i 1937, men da vi ved, at der tidligere har været spillet fodbold i Østermarie, kan man slutte sig til, at også sporten har ligget $\mathrm{i}$ dvale. ${ }^{42}$ Det ændrer dog ikke ved det afgørende for idrætshistorien i Østermarie, nemlig at da der igen kommer liv i idrætten $i$ anden halvdel af 1930'erne, spiller idrætsforeningen med sportsaktiviteter en væsentlig rolle, ligesom gymnasterne ser sig nødsaget til at modernisere aktiviteterne i form af andespil og nytårsbal. I 1939 diskuterer man badminton, og fra 1941 spilles der håndbold ved kirken med deltagelse af 19 småpiger, 20 drenge, 12 piger og 22 karle..$^{43}$

Også i Trelde ved Fredericia kan man konstatere, at gymnastikken skranter omkr. 1930. Men også her sker der en opblomstring, da håndbolden introduceres i midten af 1930 'erne. Det sker da én af landsbyens mest fremtrædende unge mænd vender hjem fra et halvandet års ophold på Ollerup med håndboldspillet $\mathrm{i}$ bagagen. $\mathrm{Og}$ selv om der i starten var en del usikkerhed med hensyn til regelfortolkningen, ${ }^{44}$ blev spillet dog hurtigt en succes, som sikrede, at gymnastikforeningen kunne overleve og endda få nyt liv. Hurtigt begyndte man selv at arrangere sportsstævner, ligesom man tog aktivt del i de omliggende landsbyers sportsfester. 45

Takket være sporten overlevede idrætten i Trelde. Én af årsagerne til boldspillets succes var måske, at det var tættere forbun- det med karlene og pigernes hverdagsliv end gymnastikken. Således spillede man de første år i Trelde håndbold i gdr. Kroghs kalveindhegning ved Strandgården, der lå centralt placeret midt i landsbyen, således at landbyens beboere uden større anstalter kunne tage et vend om til Strandgården for at se, om der foregik noget. Resultatet var, at der altid var masser af mennesker til stede ved både træning og kamp. Et andet eksempel kan illusterere: om fodbolden i Trelde fortælles det, at man en gang tabte 11-0 til Pjedsted, fordi købmand Conrad, der stod på mål, ikke ville kaste sig efter bolden, idet han havde sine nye, lyse sommerbukser på. ${ }^{46}$ Igen ser man den tætte forbindelse til hverdagslivet. Det kunne være svært at se, hvor hverdagslivet sluttede, og idrætslivet begyndte.

Så var det straks anderledes for gymnastikkens vedkommende. Her kom der ikke folk for at overvære træningen, og her gjorde man ikke gymnastik i sine nye sommerbukser. Langt mere end sporten er gymnastikken - lukket inde bag forsamlingshusets fire vægge - præget af en rumslig og tidslig parcellering, som virker eksklusivt organiserende, på den måde at der i langt højere grad end for sportens vedkommende er vandtætte skodder mellem gymnastikken som aktivitet og de $\varnothing v$ rige aktiviteter i landsbyen. Skæg for sig og snot for sig. Gymnastikken i forsamlingshuset er domineret af territorialitet og lukkede enemærker. ${ }^{47}$ Det er sporten på en multifunktionel kalveindhegning eller græsmark ikke i nær samme udstrækning. Den er mere forbundet med det omgivende pulserende, folkelige liv, end gymnastikken kunne være det. Hvor gymnastikken var forskantset i forsamlingshuset, måtte sportsfolkene til stadighed kæmpe med besværet med at skaffe en bane at spille på. Og ganske vist betød denne kamp ofte en hindring for 


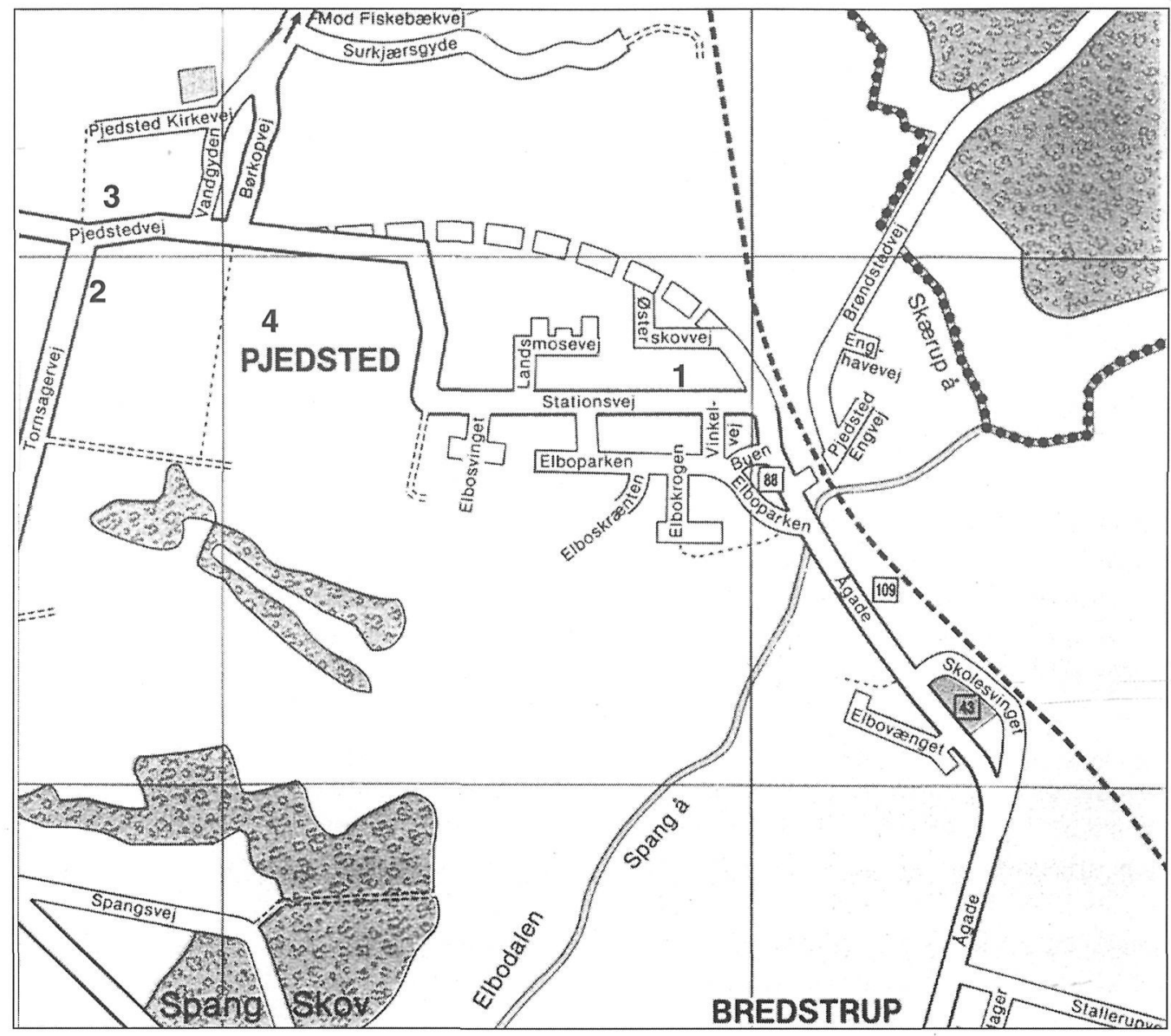

I Pjedsted ved Fredericia blev boldbanerne 4) efter 2. verdenskrig centrelt placeret midt mellem Gl. Pjedsted og Stationsbyen. Købmandsgården lå skråt overfor. Desuden var afstanden kort til både den »lille« og den »store« skole, hvor der fra first i fyrrerne blev spillet badminton og dyrket gymnastik $i$ gymnastiksalen. Placeringen udgjorde en slags kompromis mellem de to dele af landsbyen, hvor man i begyndelsen af 1930'erne havde haft fodboldbanen til at ligge i Stationsbyen 1), og derefter på Abraham Sфrensens mark bag Missionshuset 2), hvor der ligeledes blev spillet håndbold. Også på marken mellem Abraham Sфrensen og Niels Kroghs gårde 3) har der kort efter 2. verdenskrig varet spillet håndbold. Den nye placering åbnede muligheder for en nok så integrativ virkning

sportens udbredelse, ${ }^{48}$ men man med lige så stor ret sige, at gymnastikken sejrede sig ihjel i de grundmurede forsamlingshuse.

I den forbindelse har svenske ${ }^{49}$ og engelske $^{50}$ idrætsgeografiske undersøgelser (vi mangler i Danmark fortsat en idrætsgeo- grafisk forskning) af forholdet mellem idrætsanlæg og .lokalsamfund godtgjort sammenhængen mellem idrætsdeltagelse og lokalsamfund som værende betinget af dels idrætsanlæggenes fysiske placering, dels deres fysiske udformning. Her har 


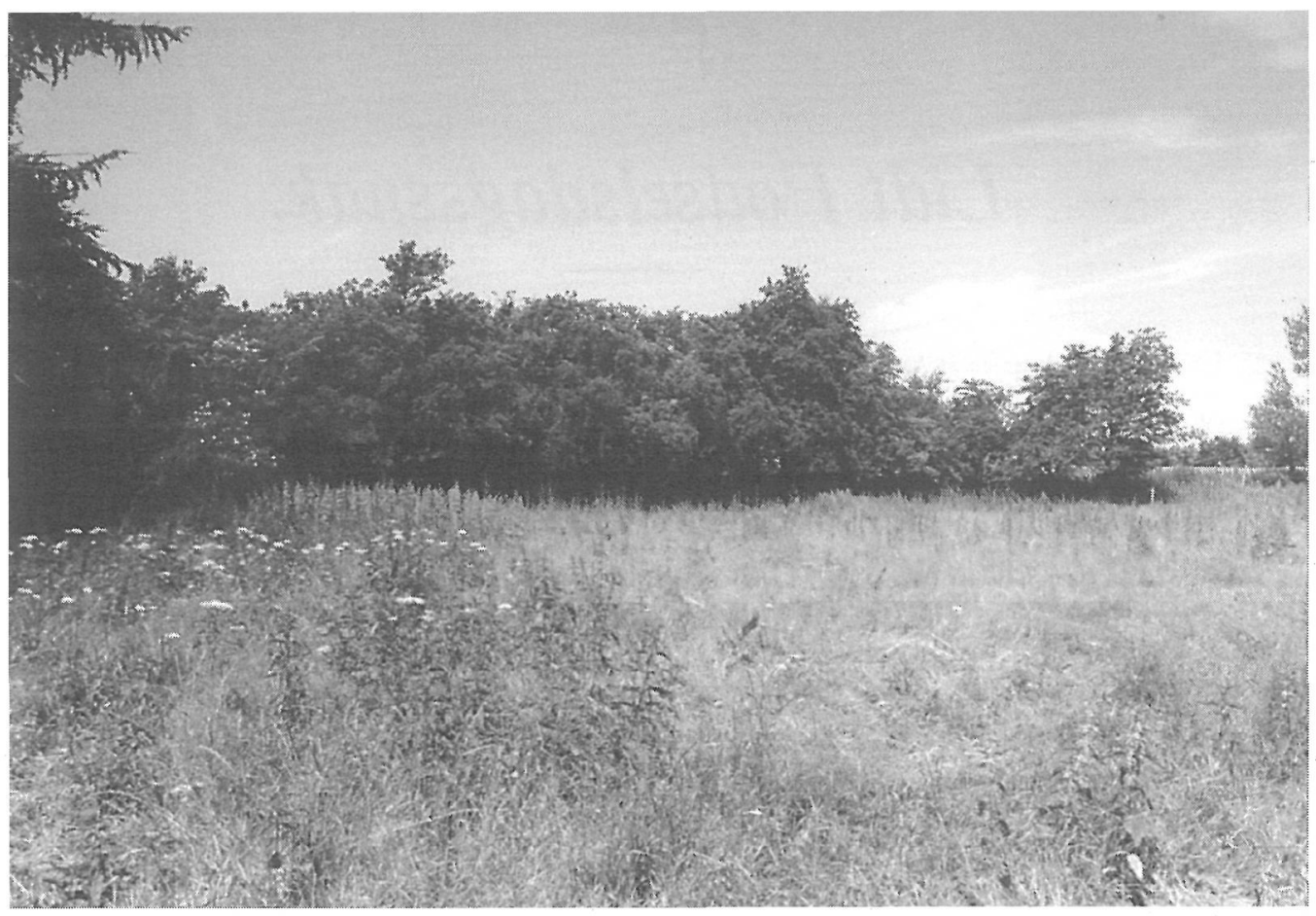

I Sdr. Vilstrup mellem Kolding og Fredericia lå håndboldbanen i denne indhegning placeret midt $i$ landsbyen, klos op ad såvel skolen som forsamlingshuset og blev derved en organisk det af landsbylivet. Foto: Troels Kayser Nielsen.

grænse-porøsiteten mellem idrætsanlæg og lokalsamfundets sociale virkelighed vist sig at være en vigtig faktor, sådan som det fremgår af ovennævnte eksempler: jo mere indelukket og territorialt præget det pågældende idrætsanlæg fremtræder, desto mindre gennemslagskraft har det socialt, medens det omvendte også gør sig gældende.

\section{Sammenfatning}

Hermed har man måske samtidig en del af forklaringen på gennembruddet for sporten på landet, som afløser for gymnastikken. Sporten var i mellemkrigsårene i kraft af sine noget tilfældige, men også fleksible baneforhold tættere på det levede liv i om- givelserne, end gymnastikken nogensinde havde været. Grænsen mellem sportspladsen og livet i landsbyen i $\varnothing v$ rigt var mere porøs end forsamlings- og $\emptyset$ velseshusets fire vægge.

Dernæst kom, at den var så meget mere dynamisk og så meget mere i tråd med den bykultur, der i mellemkrigstiden - med radio i dagligstuen, rutebiler til købstaden og biograf $\mathrm{i}$ stationsbyen - begyndte at tiltrække mange unge på landet. Den modernisering af almuen, som forsamlingshuse og missionshuse havde bidraget til en generation tidligere og givet en særlig dansk udformning, således at man med rette kan tale om en særlig dansk agrar-modernitet, blev nu suppleret med henholdsvis statsmagtens initiativer i retning af en fælles nationalkul- 


\section{Lidt Fodselsdagssnak.}

Mel.: Jeg har elsket dig, saalænge ...

Det er Fakta, at der nu et Aar er gaaet, siden vi var samlet sidst til Fodselsda', og de Resultater, der er siden naaet, har vi altsaa Lov at være stolte a', dels kom der en nyd'lig lille Klat $\mathrm{i}$ Kassen, dels har Muldga ard faaet sig et dejligt Job. Naar han træner Damerne paa Haandboldpladsen. er det Pokkers svært for ham at holde op. Skræder Larse n, han har ikke været længe om paa vores Drengehold at sætte Præg, han har nemlig lavet en Flok raske Drenge, der kan baade spille Bold og lave "Skæg".

Da Fru Christensen for rundt med D. K. W.en, var der vistnok ikke mange, der gik fri. Vognen var saa lille, at man knapt ku' se'en, mens man straks la' Mærke til, hvad der var i. Det var ikke sært, at Mændene blev varme, naar de præserteret blev for D. K. W. baade den og saa dens Indhold havde Charme. det var navnlig derfor, at den fik Sukces. Men naar nu man for omtrent en halv Snes Tusind sælge kan en Vogn, som næsten er slidt op. saa maa man da kunne sælge et Par Dusin. før Chaufførens Charme ogsaa siger Stop!

Vi har ogsaa været udenlands i Sommer; Skärrelit med samt Röstänga fik Besøg, og det kan jo hænde, at der flere kommer, næste Gang vi prove vil den samme Spog. For der er vel nok vidunderligt i Sverrig. der er ganske sjovt, og der er smukt og frit, navnlig sjovt hvis altsaa ikke man er nærig, men blot gi'r Chaufføren godt med Akvavit. Ja, derovre kan man gaa og ha' det hyg'ligt, naar man blot forstaar sig paa Naturens Smil, at en saadan Tur for nogen ender lyk'ligt. er der heller ikke no'et at sige til.
Idrætsstævner horer med til Dagens Orden, og at det skal foregaa paa Stadion, det er soleklart, men hvorfor faar mon Jorden omkring Banen ikke snart en pæn Facon. Saadan lyder det jo stadigt fra Kritikken, skal der gøres Vrovl, saa maa det ske i Aar, næste Aar saa bli'r der Gang i Mekanikken, forsaavidt man Fremtidsplanerne forstaar, for nu er der altsaa godt med Gryn i Kassen, og hvorfor skal vi saa nojes med en Mark. Jeg tør næsten vædde paa, at Idrætspladsen næste Aar maa døbes om til Idrætspark.

Eigil Christensen skal ha' lidt mere Mave, det er nemlig den Slags Ting, der gi'r Respekt. og de Spillere, som ingen Maal kan lave, de skal ha', ja, de skal ha' en Gang Konfekt. Jorgen Maalmand, som vi allesammen kender, blev jo fælt brændt af dengang han vandt en And, han ber næste Gang vi spille skal om Æinder, og han vinder, mindst da ha' en Pelikan. Muldgaard skal ha' Svommehal til sine Piger, Skræder Larsen skal ha' et Par ekstra Hold Hver af Spillerne skal, efter hvad man siger, ha' foræret hver en Hjemmetræningsbold!

Ja, som sagt i Aar der kom en Del i Kassen, og cet har Bestyrelsen skam Ære a',

det er den, der holde sammen skal paa Massen, og det har den gjort og gor dén Dag i Da'. Men den har tillige gode Assistenter; gode Assistenter, de er Penge vard, gode Assistenter, de gi'r gode Renter, naar der sælges skal en D. K. W. især. Men skal Sporten her i Byen nyde Fremme, ja, saa maa vi allesammen hjælpe til, naar der kaldes, saa maa ingen blive hjemme, Sport er Sundhed, Sport er ungdomsglade Smil.

Denne »Fødselsdagssang « fra Espergärde Idrcetsforening fortaller på sin egen måde om hverdagslivet $i$ en idratsforening. Den $D K W$, der omtales $i$ sangen, er den bil, som foreningen $i 1937$ bortloddede for at få penge $i$ kassen. (Kilde: Espergarde Idratsforening. 1935-1985. Espergarde 1985).

tur (radioen) og privatkapitalistiske underholdningsinitiativer (film og triviallitteratur). Ind i dette billede passede sporten med dens fart og flugt, dens konkurrencer og præstationer perfekt.

Dernæst kan man, som udflugterne i 
Gudbjerg, ballerne på Hotel Østermarie og sportsstævnerne i Trelde viser, heller ikke se bort fra den nye festdimension, som sporten åbnede mulighed for. Ikke mindst central i den forbindelse er »sportsfesten som fast institution. Den havde bl.a. bilismen og de andre nye kommunikationsforbindelser som forudsætning, idet man nu man på sin frisøndag enten på cykel eller i bil kunne mødes med udenbys hold for at spille om nåle, eller plader til fanen. Enten der nu var besøg udefra, eller man selv skulle rejse afsted til en nabolandsby for at spille, indebar det en udvidelse af erfaringsrepertoiret i forhold til gymnastikkens indelukker. Dels var der selve de sportslige aktiviteter, som kunne give anledning til alskens (kropslige) sammenligninger af folk fra begge $k ø n$, dels var der de baller, der - i forsamlingshuset med levende musik fulgte efter selve idrætten. »Kærestemarkedet « blev hermed udvidet betragteligt, og omgangen mellem kønnene blev friere. På et billede i Gårslev Idrætsforenings 50 årsjubilæumsskrift kan man se et sommerbillede med nogle par i shorts i forgrunden, medens balkjolen hænger til luftning på en grangren i baggrunden. Billedet er taget fra et idrætsstævne en sommer i Kollemorten, i slutningen af 1940'erne kan man se på tøjet. De unge fra Gårslev var her kommet mere end $50 \mathrm{~km}$ hjemmefra. I mellemkrigstiden nøjedes man med mindre, men situationen var den samme. De idrætslige sognebånd var ved at blive sprængt.

Disse sportsfester skal endelig også ses i lyset af den $\emptyset$ gede erotisering af idrætslivet, som finder sted i mellemkrigstiden, og som formodentlig er yderligere en årsag til sportens gennembrud. Ikke mindst fordi sporten i sommerhalvåret var i stand til at bringe de to $k ø n$ nærmere hinanden. I gymnastikkens velmagtsdage havde vilkåret, i idrætssammenhæng, i regelen været, at man måtte vente på hinanden i sne og sjap ved forsamlingshuset, indtil gymnastikken var forbi, så at karlen kunne følge pigen $»$ hjem $\ll$. Med sportens indtog ændredes billedet. Dels havde man nu de lyse sommeraftener til rådighed. Dels havde man aktiviteter for både karle og piger, som gjorde at man kunne se hinanden $\mathrm{i}$ fuldt kropsligt vigør. Som regel blev træning $\mathrm{i}$ håndbold for piger og fodbold for karle af praktiske årsager henlagt til de samme aftener - hvis der da ikke var tale om, at også karlene spillede håndbold, således at man havde fælles interesse.

Den erotiske dimension er sandsynligvis en væsentlig del af historien om sportsgennembruddet i mellemkrigstiden - og hvis man i forbindelse med »opdagelsen af kroppen « i denne periode kun har Arne Ungermans tegning til Piet Heins digt Pigedyret i tankerne, skal man kikke i lokalarkiverne efter billeder af sportslivet $i$ sommerhalvåret - for slet ikke at tale om Niels Bukh-gymnasterne i de »små sorte«. Her foregik et veritabelt ungdomsoprør som dem der sad på flæsket, i bogstavelig forstand - ikke altid brød sig om. Som en gårdmandskone i Brøndsted en gang så rigtigt sagde til én af sine tjenestepiger: »Det er jo ikke det at gå til bal - det er det bagefter «. Det ungdommelige bal- og idrætsliv var ikke altid så let at fordøje for velbjærgede gårdmandsmatroner, samtidig med at de »uartige« sportspiger hermed fik yderligere appetit på tilværelsen - og sporten - $\mathrm{i}$ frisk og folkelig fornøjelighed.

Hvor højskolemanden Grønvald Nielsen fra Vestbirk endnu i 1888 kunne holde tale om gymnastikkens sexuelle fascinationskraft og stille den elegante gymnast op overfor den klumpe-dumpede »lemmedasker «, som ikke gjorde gymnastik, ${ }^{51}$ var der nu kommet andre boller på suppen. Gymnasten hørte i for høj grad vinteren til. 
Den mørke tids charmør slog ikke rigtigt til i forhold til de lyse sommerafteners rigere muligheder. Det var ikke længere nok kun -at være en »vinterven «. Idrætslivet var takket være den unge folkelige sport på vej til at blive en helårsbeskæftigelse. Det kom også gymnastikken til at nyde godt af. I stedet for at gå en stille død i møde i takt med foreningskrisen generelt $\mathrm{i}$ begyndelsen af 1930'erne, kunne der i 1930'ernes anden halvdel med sporten (håndbold, fodbold, badminton) som drivkraft pustes nyt liv i idrætsforeningerne. Det bevirkede, at også gymnastikken overlevede på landet. I stedet for et modsætningsforhold mellem gymnastik og sport bør man derfor snarere tale om et suppleringsforhold - i det mindste hvis man har det sociale liv i og omkring idrætten i tankerne. Vel kan man også finde eksempler på, at gymnastik og boldspil på lokalt plan holdes adskilt i to foreninger, sådan som tilfældet var i den højskoleprægede landsby Skårup på Sydfyn, ${ }^{52}$ men i hovedtrækkene går tendensen landet over i retning af samarbejde, og som vi har set ovenfor, er billedet end ikke på Sydfyn entydigt: i Gudbjerg blev boldspil og gymnastik to sider af samme foreningssag, til berigelse for begge dele. I As ved Horsens er det gymnastikforeningen, som indfører håndbold i 1930'erne, medens boldklubben koncentrerer sig om fodbold, ${ }^{53}$ hvorefter ungdomsforeningen, boldklubben og gymnastikforeningen så går sammen i 1936, i erkendelse af fælles interesse.

\section{Afslutning}

Den særegne danske dobbeltorganisering af idrætten er næppe udtryk for den store forskel, hvad angår aktiviterne, aktiviteternes udførelse og det sociale liv omkring dem. I adskillige idrætsforeninger aner medlemmer ikke, om de er medlem af den ene eller den anden af de store hovedorganisationer. ${ }^{54}$ Langt snarere synes der at være tale en institutionel og organisatorisk træghed, der - selvreferentielt - refererer til sin egen organisatoriske historie, snarere end til idrættens historie.

Denne organisatoriske historie synes imidlertid ikke at være knyttet til en idrætslig modsætning. Det er svært at se en modsætning mellem gymnastik og sport i begge disse idrætstypers etableringsfase $i$ årene omkr. århundredskiftet 1900 . Her var der tværtimod tale om en høj grad af konsensus, med sundhed, modernisering og civilisatorisk omsorg for ungdommen, både hvad angår dens »sjælehusholdning « og dens adfærdsmæssige repertoirer, som det centrale, ${ }^{55}$ ligesom der i begge kredse var en markant opslutning om teknik og videnskab, orden og perfektion. ${ }^{56}$ Ejheller er der, i det mindste på landet, tale om et eklatant modsætningsforhold $i$ trediverne, når spørgsmålet gælder den praktiske tilrettelæggelse af idrætsforeningslivet og af aktiviteterne $\mathrm{i}$ disse foreninger.

Langt mere synes den organisatoriske modsætning at være knyttet til den særegne danske kombination af agrarmodernitet og nationalisme, der så dagens lys i slutningen af 1800-tallet, og som ikke mindst efter 1 . verdenskrig disponerede for, at især den ene fløj i dansk idræt kom til at varetage en særlig dansk, national stil..$^{57}$ Eller sagt på en anden måde: modsætningen mellem de to store hovedorganisationer i dansk idræt forekommer mest af alt at være af stilistisk og retorisk art. Den vedrører mere en kulturel forskel end en idræts-social. En sådan kulturel og stilistisk forskel skal man til gengæld, generelt, være varsom med at underkende. Heri må man give Ove Korsgaard ret.

Blot har denne stilistiske og retoriske forskel ikke så meget at skulle have sagt for 
selve idrætslivets dagligdag. Og da slet ikke i trediverne. Snarere er stilens integrative effekt som led i opbygningen af et livsstils-tilhørsforhold et 1980'er-fænomen, hvor spørgsmålet om positionering $\mathrm{i}$ identitetsøjemed har været så relevant. Som sociologen Georg Simmel en gang har sagt om behovet for stil, midt mellem den sociale og den kulturelle virkelighed: hvis du ikke selv er en enhed, så slut dig til én. Det er måske derfor, at spørgsmålet om stil og kulturelle iscenesættelser har trængt sig så mærkbart på gennem de senere år - ikke mindst $\mathrm{i}$ idrætslivets organisatoriske verden. Et sådant behov skal man også være varsom med at underkende, når det nu er den prekære identitet, det gælder.

I 1930'erne, på landet i Danmark, var situationen anderledes. Her gjaldt det nok så meget om at holde liv i idrætten som sådan. Hvis der i den forbindelse var tale om stil, drejede det sig mere om en fastholdelse resp. etablering af en særlig frisk og djærv idrætsstil, ikke om specielle afdelinger heraf. Den slags sofistikerede spørgsmål tilh $\varnothing-$ rer langt snarere et tidehverv, hvor idrætten er kommet i sikkerhed og optræder som en selvfølgelig og selvreferentiel del af det danske samfund, der ikke behøver at legitimere sig udadtil.

\section{Noter}

1. Ove Korsgaard: Kampen om kroppen. København 1982, s. 167 f. Sml. også Ove Korsgaard: Krop og kultur. Odense 1986, sp. s. $75 \mathrm{ff}$.

2. Ove Korsgaard: Krop og kultur. Odense 1986, 77 ff.

3. Ibid, s. 79.

4. Olav Vang Lauridsen og Jens Peter Harbo (red.): Slagten Lauridsen på Grønvang, Vejen og nogle af dens slagtsforbindelser. Vejen 1921, s. 162.

5. Hans Lund: Askov Højskole 1865-1915. Kbhvn. 1965, s. 260.

6. Ibid, s. 262.

7. Olav Vang Lauridsen og Jens Peter Harbo (red.): Slagten Lauridsen på Grønvang, Vejen og nogle af dens slagtsforbindelser. Vejen 1921, s. 153.

8. Søren Alkærsig: Vejen Sogn i Malt Herred, bd. 2. Vejen 1940, s. 447.

9. Leif Christensen: Vejen Sportsforening gennem 100 år. Vejen 1990, s. 20.

10. Olav Vang Lauridsen og Jens Peter Harbo (red.): Slagten Lauridsen på Grønvang, Vejen og nogle af densslagtsforbindelser. Vejen 1921, s. 199.

11. Ibid, s. $216 \mathrm{f}$.

12. Leif Christensen: Vejen Sportsforening gennem 100 år. Vejen 1990, s. 13.

13. Niels Kayser Nielsen: Krop og oplysning. Om kropskultur i Danmark 1780-1900. Odense 1993, s. 125 .

14. Leif Christensen: Vejen Sportsforening gennem 100 år. Vejen 1990, s. 19.

15. Niels Kayser Nielsen: Højskole og sport - om idratten $i$ Vejen, in: Magasin fra Det kgl. Bibliotek, vol. 9, nr. 2 (1994), s. 29 ff.

16. Leif Christensen: Vejen Sportsforening gennem 100 år. Vejen 1990, s. 45

17. Ibid, s. 36 .

18. DIF's årsberetning 1919. København 1920, s. XXVI.

19. DIF's årsberetning 1917. København 1918, s. XX.

20. DIF's årsberetning 1921. København 1922, s. XXXVI.

21. DIF's årsberetning 1923. København 1924, s. 52.

22. Enzio Sevon: Svenska Finlands Idrottsförbund 1912-1962. Helsingfors 1962, s. 24.

23. DIF's årsberetning 1922. København 1923, s. 69.

24. Ibid, s. 68. 
25. Ibid, s. 69.

26. Niels Kayser Nielsen: Sport og bondekultur - om foreningsliv i provinsen i mellemkrigstiden, in: Fortid og Nutid 1995: 1 (in print).

27. Niels Kayser Nielsen: Foreningskriser $i$ Österbotten og Jylland $i$ mellemkrigstiden - en lokalhistorisk sammenlignende studie, in: Max Engman og Henrik Stenius (red.): Svenskt föreningsliv i Finland. Ekenäs 1995 (in print).

28. Peter Frandsen og Ole Madsen (red.): Blåhøj idrat gennem tiderne og Blåhøj IF gennem 50 år. Blåhøj 1986 passim, se spec. s. $57 \mathrm{ff}$.

29. Orla Nielsen og Steen Hebsgaard (red.): Idratsliv i Ikast gennem 50 år. Ikast 1985, s. 15.

30. Børge Hede: Assere. Foreningsliv gennem 100 år. As 1986, s. 47.

31. Niels Kayser Nielsen: »og en lille svingom« træk af idrætslivet i Herslev, in: Per Jørgensen m. fl. (red.): Idratshistorisk Årbog 1986, s. 143 ff.

32. Jonas Frykman: Becoming the Perfect Swede in: Ethnos, vol. 58:3-4 (1993), s. 259 ff.

33. Jvf. Carl-Johan Nielsen: Da Aulum fik sit friluftsbad, in: Benny Boisen (red.): Hardsysselfolk 3 Mennesker og handelser $i$ Vestjylland. Struer 1983, s. $43 \mathrm{ff}$

34. John Skjerning (red.): Gårslev Gymnastikforening 50 år. 1941-1991. Jubilæumstidende 1-6, 1991, hæfte 2, upag.

35. Jørgen Jacobsen (red.): Gudbjerg Idratsforening, 1966, s. $47 \mathrm{f}$.

36. Ibid, s. 77

37. Niels Kayser Nielsen: Fra krostue til hal - om badmintonspillet i mellemkrigstiden, in: Tidsskrift for Idrcet 1994: 1, s. 6 ff.

38. Jørgen Jacobsen (red.): Gudbjerg Idratsforening, 1966, s. 47.

39. Bornholms Boldspil-Union 1907-1957. Rønne 1957, s. 12.

40. Vilhelm Kjølbye: Østermariebogen. Et bornholmsk sogn 1875-1975. Rønne 1977, s. 69.

41. Ibid, s. 70.

42. Ibid, s. 79 .

43. Ibid, s. 76 .

44. Erling Weile(red.): Livet $i$ landsbyen. Kultur-og fritidsaktiviteter $i$ Vejlby sogn 1868-1988. Fredericia 1988 , s. 56
45. Niels Kayser Nielsen: To idrætsforeninger på landet i mellemkrigstiden - Trelde og Herslev, in: Vejle Amts Årbog 1994 (in print).

46. Jvf. Erling Weile (red.): Livet i landsbyen. Kulturog fritidsaktiviteter $i$ Vejlby sogn 1868-1988. Fredericia 1988, s. 90.

47. Niels Kayser Nielsen: Krop og oplysning. Om kropskultur i Danmark 1780-1900. Odense 1993, s. $138 \mathrm{ff}$.

48. Niels Kayser Nielsen: Fra gymnastik til sport. Om idrætten på landet i mellemkrigstiden, in: Journalen. Tidsskrift for lokal- og kulturhistorie 1994: 4, s. 13.

49. Olof Moen: Idrottsanläggningar ocg idrottens rumsliga utveckling $i$ svenskt stadsbyggande under 1900-talet. Göteborg 1992 og samme: Från bollplan till sportcentrum. Sockholm 1992.

50. John Bale: Landscapes of Modern Sport. Leicester 1994.

51. Niels Kayser Nielsen: Krop og oplysning. Om kropskultur i Danmark 1780-1900. Odense 1993, s. $133 \mathrm{f}$.

52. Erik Pold: Sports- og Gymnastikforeningerne 1930-60. En mikroundersøgelse af idratsmiljøerne i Skårup og Kauslunde. Upubliceret specia- leafhandling. Historisk Institut, Odense Universitet 1993 .

53. Børge Hede: Assere. Foreningsliv gennem $100 \stackrel{\mathrm{r}}{\mathrm{r}}$. As 1986, s. 76.

54. Niels Kayser Nielsen: Stil og ballade. Modstridende tendenser og paradokser i 1980'ernes kropskultur. Odense 1994, s. $155 \mathrm{ff}$.

55. Niels Kayser Nielsen: Idræt og offentlig støtte 1861-1914 - set i et civilisationsperspektiv, in: Fortid og Nutid, bd. 36, hefte 3 (1989), s. 180 ff, se spec. s. $191 \mathrm{f}$.

56. Niels Kayser Nielsen: Stil og ballade. Modstridende tendenser og paradokser i 1980'ernes kropskultur. Odense 1994, s. $50 \mathrm{ff}$.

57. Niels Kayser Nielsen: Hälsa och idrott - en modern och nationell angelägenhet, in: Svenska IdrottshistoriskaFöreningens Årsbok 1994. Stockholm 1994, s. $61 \mathrm{ff}$. 